\title{
Health Risk Assessment of Trace Metals in Drinking Water Consumed in Dakar, Senegal
}

\author{
Jessica Carmelia Mbemba Peleka, Cheikh Diop*, Robert Faomowe Foko, \\ Mouhamadou Lamine Daffe, Mamadou Fall
}

Laboratory of Toxicology and Hydrology (LTH), Department of Pharmacy, Faculty of Medicine, Pharmacy and Dentistry (FMPO), Cheikh Anta Diop University (UCAD), Dakar, Senegal

Email: *cheikh4.diop@ucad.edu.sn

How to cite this paper: Mbemba Peleka, J.C., Diop, C., Faomowe Foko, R., Daffe, M.L. and Fall, M. (2021) Health Risk Assessment of Trace Metals in Drinking Water Consumed in Dakar, Senegal. Journal of Water Resource and Protection, 13, 915-930. https://doi.org/10.4236/jwarp.2021.1312049

Received: October 14, 2021

Accepted: November 29, 2021

Published: December 2, 2021

Copyright $\odot 2021$ by author(s) and Scientific Research Publishing Inc. This work is licensed under the Creative Commons Attribution International License (CC BY 4.0).

http://creativecommons.org/licenses/by/4.0/

\begin{abstract}
Water contamination by chemical pollutants is increasingly associated with waterborne diseases worldwide. The objective of this study is to assess the chemical health risk associated with drinking water consumption in Dakar, Senegal. The methodology adopted in this study is based on the determination of trace metals $(\mathrm{Cd}, \mathrm{Pb}, \mathrm{Fe}, \mathrm{Cu}$ and $\mathrm{Mn})$ in human drinking water by flame atomic absorption spectrometry, the estimation of the exposure of populations of the study area on the basis of the quantity of water consumed daily and the determination of the hazard quotient which allows estimating the health risk. The results indicate unacceptable levels of $\mathrm{Pb}$ and $\mathrm{Cd}$ in the water according to World Health Organization (WHO) guidelines, while the concentrations of $\mathrm{Fe}, \mathrm{Cu}$ and $\mathrm{Mn}$ are below the regulatory values. The hazard quotient (HQ) is in the majority of samples higher than 1 in children and infants for scenario 1 (based on WHO data), reflecting a high risk for this target. In scenario 2 based on consumption data from the populations studied, the HQ is greater than 1 only in heavy consumers. The drinking water consumed by Dakar population presents health risks related to $\mathrm{Pb}$ and $\mathrm{Cd}$, particularly for infants, children and heavy consumers, hence the need to strengthen the water treatment system before home consumption.
\end{abstract}

\section{Keywords}

Drinking Water, Trace Metals, Health Risk, Senegal

\section{Introduction}

Water is essential for life, and the availability of good quality water helps to promote and sustain life [1] [2] [3]. Good quality water is water for drinking or food preparation that is chemically and microbiologically safe. Thus, it is a water 
that has been treated and/or filtered to meet the established consumption standards depending on whether one belongs to a region or another [4] [5]. It can come from surface water such as rivers, streams or groundwater such as springs, wells and boreholes [4].

Water quality remains a global public health concern. This takes into account the physical, chemical, radiological and biological characteristics of water that must meet the drinking water needs of humans and animals [6] [7] [8]. However, drinking water can be contaminated from a variety of sources. Among the many pollutants that can contaminate water resources, trace metals are receiving more attention because of their toxicity at low concentrations. The contamination of water by these trace metals can originate from natural processes or from anthropogenic pollution. The latter can contribute to modifying the properties of water and make it a vehicle for biological (bacteria, parasites...) and chemical (lead, cadmium, nitrates, pesticides...) hazards [9] [10]. Trace elements concentrations in water naturally may depend on the local geology, hydrogeology and geochemical characteristics of the aquifer (e.g. weathering and erosion of bedrock, ore deposits), while anthropogenic activities such as mining, agricultural wastewater discharges may lead to the contamination of water sources with trace metals. Due to their toxicity, persistence and bio-accumulative nature, the presence of trace metals in the environment can contribute to the deterioration of water quality and consequently pose significant health risks. Water quality is therefore a health requirement and a key component of health protection policies. Thus, it is easy to understand the commitment of the international community for a better access to water. It is in this perspective that the Sustainable Development Goal 6 (SDG 6) focuses on the availability and sustainable management of water resources.

In Senegal, the issue of water management is a thorny problem due to the scarcity of this resource and its fundamental nature for sustainable development. Over the last few decades, Senegal has been characterized by a significant drop in rainfall combined with a galloping demography and rapid and uncontrolled urbanization with a considerable impact on access to water. In urban centers such as Dakar, the water needs of the population, particularly those with average or low incomes, are met by selling drinking water in bags on the public highway. However, this flourishing activity risks endangering the health of the consumer since in $41 \%$ of cases, these waters present a fecal contamination [11]. In addition to this microbiological contamination, chemical contamination (metallic trace elements, pesticides, organic compounds) is probably omnipresent (untreated domestic and industrial waste) but little or not characterized. Indeed, the ingestion of chemical hazards through the consumption of contaminated drinking water can thus be responsible for serious illnesses especially in children [12] [13]. However, the potential levels of chemical contamination of these waters as well as their impacts on health remain to be documented for the Senegalese consumer. Indeed, the chemical pollution of water in Senegal and its health impact are poorly known while many metal compounds in water $(\mathrm{Pb}, \mathrm{Cd})$ are 
known for their established toxicity [14].

It is in this context that our study aims to determine the likely contamination of different sources of drinking water by trace metals $(\mathrm{Pb}, \mathrm{Cd}, \mathrm{Cu}, \mathrm{Fe}, \mathrm{Mn})$ and to assess the risk for the Senegalese consumer.

\section{Methodology}

\subsection{Study Zone}

The study was conducted in the city of Dakar (Figure 1) in Senegal. It is located in the extreme west of the Cape Verde Peninsula, on the Atlantic Ocean. It is the political, economic and cultural capital of Senegal. Dakar region covers an area of $550 \mathrm{~km}^{2}$ with approximately 3,938,358 inhabitants. Dakar is mainly supplied with drinking water from Lake Guiers, which is located about $320 \mathrm{~km}$ from the capital, but also from boreholes in some communes.

\subsection{Study Population and Selection Criteria}

In this work, the study population consisted of households, public water supplies and the various brands of bottled and sachet water sold and consumed by the inhabitants of Dakar. The questionnaires were administered to households representative of the population in three districts of the Dakar region (Medina, Grand Dakar, Fann). Households were selected at random. To be eligible to participate in the study, a person had to be a member of one of these households, have lived in Dakar for more than one year, and be able to answer the questions. Anyone deemed ineligible to answer the questions and/or residing in the Dakar region for less than one year was excluded from the study.

\subsection{Data Collection Tools and Methods}

A data entry form in the form of a questionnaire is the collection instrument used in this study to collect consumption data from the population. The Google

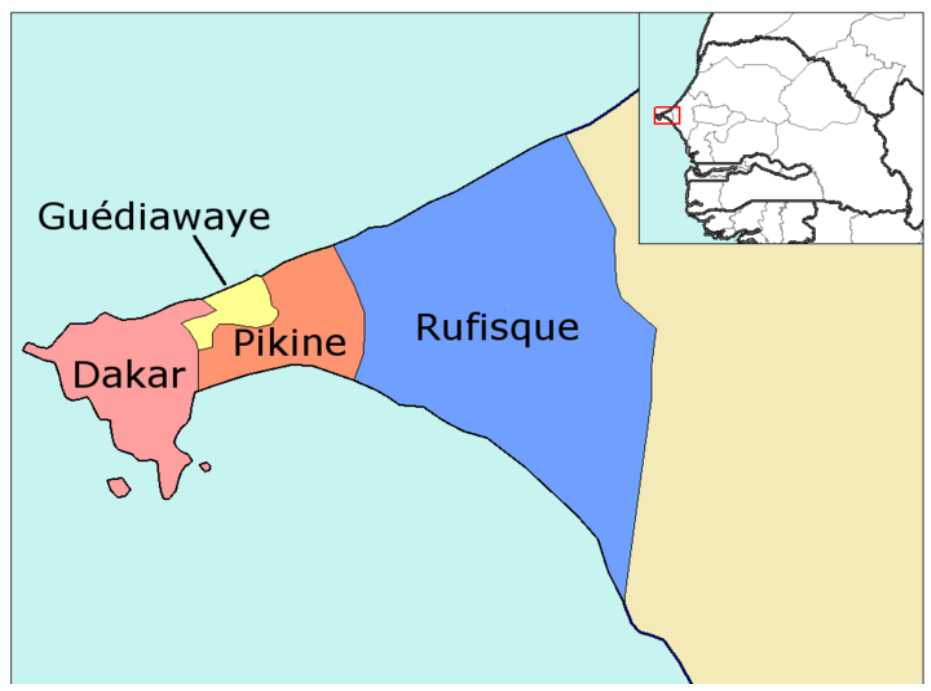

Figure 1. Study zone. 
Form application was used to conduct the survey and obtain information on socio-demographic characteristics, water consumption preferences, average daily water consumption volume, and water quality satisfaction. A pilot survey identified difficulties in administering the questionnaire and after the survey was completed, corrections were made. All data on the population and on the different waters were identified while preserving the confidentiality of the respondents and the water samples.

\subsection{Drinking Water Sampling}

The sampling of the different waters was done during three campaigns that took place during the period from December 2020 to March 2021. Sampling was done at retail outlets for bagged and bottled drinking water and at randomly selected households for tap water. Prior to each tap water collection, the tap was opened at a medium flow rate for 5 minutes [15]. Thereafter, the tap flow rate was reduced and held constant to allow for splash-free filling of the bottles. For each site, a volume of $300 \mathrm{~mL}$ of water was collected. After collection, the individual containers were tightly sealed and the water samples transported to the laboratory for analysis. A total of 18 composite samples (mixture of 3 subsamples) were collected including 10 bagged water samples (S1, S2, S3, S4, S5, S6, S7, S8, S9, S10), 4 bottled water samples (B1, B2, B3, B4) and 4 tap water samples (R1, R2, R3, R4). Each of the samples was collected three times during the three campaigns. From the information collected, the bagged waters were table waters and the bottled waters were mineral spring waters.

\subsection{Measurement of Physico-Chemical Parameters}

$\mathrm{pH}$ and conductivity were measured in situ using the SANXIN Model SX736 $\mathrm{pH} / \mathrm{mV} / \mathrm{Cond} / \mathrm{DO}$ Meter, which is a multiparameter measuring device equipped with a $\mathrm{pH}$ glass electrode, a conductivity electrode and a temperature probe. For trace metals, the water samples were first filtered through a $0.45 \mu \mathrm{m}$ PTFE syringe filter and then acidified with three drops of $67 \%$ nitric acid. The determination of the trace metals $(\mathrm{Pb}, \mathrm{Cd}, \mathrm{Fe}, \mathrm{Cu}, \mathrm{Mn})$ was done using atomic absorption spectrophotometry (Agilent Technologies 200) with 240FS AA flame.

All glassware was washed with detergents, rinsed with distilled water and dried in a fume hood before use. A calibration and rinsing blank for the apparatus was prepared; it was a 5\% nitric acidified water solution prepared under the same conditions as the samples. This blank allowed us to assess the background contamination of the samples to ensure the accuracy of the data. The analyses were performed in triplicate.

\subsection{Estimation of Risk from Trace Metals}

In this study, the human health risk from exposure to trace metals was assessed by ingestion of water only. Thus, exposure was estimated based on average daily water consumption data by age group, as well as average weight for each group. 
Two scenarios were considered. The first scenario is based on WHO estimates of average daily drinking water consumption of $2 \mathrm{~L}$ for adults, $1 \mathrm{~L}$ for children and $0.75 \mathrm{~L}$ for infants. The second scenario, which takes into account high, medium and low consumers, refers to the results of the population consumption survey while maintaining the values of the average weight as estimated by the WHO. The average daily dose of exposure to trace metals through the consumption of contaminated water is determined using the formula (Equation (1)):

$$
\mathrm{ADD}=(C \times Q) / P
$$

ADD: Average Daily dose $(\mathrm{mg} / \mathrm{kg} / \mathrm{d})$ of trace metals in water

$C$. Trace metals concentration of drinking water $(\mathrm{mg} / \mathrm{L})$;

Q. Quantity of water consumed per day ( $\mathrm{L} / \mathrm{d})$;

$P$. Body weight $(\mathrm{kg})$; infants from 0 to 2 years $=5 \mathrm{~kg}$, children from 2 to 15 years $=10 \mathrm{~kg}$ and adult $=60 \mathrm{~kg}$.

The non-carcinogenic risk estimate for the oral exposure route (water consumption) was calculated using the Toxicological Reference Values for lead $(0.0035 \mathrm{mg} / \mathrm{kg} / \mathrm{d})$ and cadmium $(0.001 \mathrm{mg} / \mathrm{kg} / \mathrm{d})$ according to literature data as follows (Equation (2)) [16]:

$$
\mathrm{HQ}=\mathrm{ADD} / \mathrm{TRV}
$$

HQ: Hazard Quotient,

ADD: Average Daily Dose (mg/kg/d),

TRV: Toxicological reference value ( $\mathrm{mg} / \mathrm{kg} / \mathrm{d})$,

If $\mathrm{HQ}<1$ : the occurrence of a health risk is unlikely,

If $\mathrm{HQ}>1$ : the occurrence of a health risk cannot be excluded.

\subsection{Statistical Analysis}

At the end of the survey and the different analyses, the data were compiled in an Excel file. Data analyses were performed using SPSS 26.0 (Statistical Package for the Social Sciences, Paris, France): p value less than 0.05 was considered significant. Sociodemographic characteristics of the study population, water consumption levels, as well as physicochemical parameters of drinking water were expressed as mean value \pm standard deviation and range (min; max). Comparisons were made between water types with respect to their trace metal content (Kruskal Wallis-test).

\section{Results and Discussion}

\subsection{Sociodemographic Characteristics of the Population}

Table 1 presents the demographic characteristics of our population. Our study population is composed of 122 people, 66 of whom are women and 56 men. More than half of the respondents were between 25 and 34 years old (56.6\%) and $65.6 \%$ were students. Liberal professions represent $12.3 \%$ of our workforce, followed closely by office workers (11.5\%) and those who engage in other types of activities represent $10.6 \%$ overall. 
Table 1. Sociodemographic characteristics of the population.

\begin{tabular}{ccc}
\hline Variable & Frequency & Percentage (\%) \\
\hline Sex & 56 & 45.9 \\
Men & 66 & 54.1 \\
Women & & \\
\hline Age & 42 & 34.4 \\
$18-24$ & 69 & 56.6 \\
$25-34$ & 8 & 6.6 \\
$35-44$ & 1 & 0.8 \\
$45-54$ & 1 & 0.8 \\
$55-64$ & 1 & 0.8 \\
$65+$ & & 65.6 \\
Profession & 80 & 11.5 \\
Student & 14 & 12.3 \\
Office worker & 15 & 10.6 \\
Liberal profession & 13 & \\
Other & & \\
\hline
\end{tabular}

Our results (Table 2 ) show that $72.1 \%$ of the respondents regularly buy water for consumption, and $27 \%$ said they do not consume tap water compared to $73 \%$ who regularly consume tap water. As for the preference for the type of water consumed and the level of satisfaction with its quality, $71.3 \%$ said they preferred bottled water, $23.8 \%$ preferred tap water and $4.9 \%$ preferred bagged water, with $58.2 \%$ saying they were satisfied with the quality of the water they consumed. The average volume of water consumed per day is 1.5 liters for our study population, with a lower consumption of $0.400 \mathrm{~L}$ and a higher consumption of 4.800 L (Table 2).

\subsection{Physico-Chemical Parameters}

The results of the physico-chemical analysis of the different samples show that the $\mathrm{pH}$ of the bagged waters varied between 7.54 (S5) and 8.06 (S4), that of the bottled waters between 6.43 (B2) and 7.09 (B3) and between 7.07 (R2) and 7.50 (R3) for tap waters. Comparative analysis of these values shows that the average $\mathrm{pH}$ is relatively low for bottled water $(6.80 \pm 0.27)$, followed by tap water $(7.26 \pm$ $0.19)$ and bagged water $(7.83 \pm 0.16)$ (Table 3$)$. These different $\mathrm{pH}$ values are globally within the range of 6.5 to 8.5 recommended by the WHO for drinking and potable waters, resulting in an acceptable $\mathrm{pH}$ [17]. Furthermore, natural mineral waters cannot be treated in any way other than separation into naturally occurring elements, which may also be the reason for their slightly acidic $\mathrm{pH}$ values [13]. In contrast to natural mineral waters, packaged drinking waters, like tap waters, are of underground or surface origin and are subject to treatment, 
Table 2. Drinking water consumption habits.

\begin{tabular}{|c|c|c|c|}
\hline Variable & Frequency & Percentage (\%) & {$[\min ; \max ]$} \\
\hline \multicolumn{4}{|c|}{ Preference on the type of water consumed } \\
\hline Tap & 29 & 23.8 & \\
\hline Bottle & 87 & 71.3 & \\
\hline Bag & 6 & 4.9 & \\
\hline \multicolumn{4}{|c|}{ Regular purchase of drinking water } \\
\hline Yes & 88 & 72.1 & \\
\hline No & 34 & 27.9 & \\
\hline \multicolumn{4}{|c|}{ Consumption of tap water } \\
\hline Yes & 89 & 73.0 & \\
\hline No & 33 & 27.0 & \\
\hline \multicolumn{4}{|c|}{ Average amount of daily consumption (L) } \\
\hline Tap & 3.692 & & {$[0.800-4.800]$} \\
\hline Bottle & 1.55 & & {$[0.500-2.000]$} \\
\hline Bag & 0.476 & & {$[0.400-1.600]$} \\
\hline \multicolumn{4}{|c|}{ Satisfaction with water quality } \\
\hline Yes & 71 & 58.2 & \\
\hline No & 51 & 41.8 & \\
\hline
\end{tabular}

Table 3. Physico-chemical parameters of drinking water.

\begin{tabular}{ccccc}
\hline Water sample & $\mathrm{pH}$ & Mean \pm SD & Conductivity $(\mu \mathrm{S} / \mathrm{Cm})$ & Mean \pm SD \\
\hline S1 & 7.88 & 479.33 & \\
S2 & 7.82 & 471.67 & \\
S3 & 7.96 & 478.33 & $586.97 \pm 175.72$ \\
S4 & 8.06 & 655.33 & \\
S5 & 7.54 & $7.83 \pm 0.16$ & 691.00 & \\
S6 & 7.64 & & 362.33 & \\
S7 & 7.88 & & 513.00 & \\
S8 & 7.77 & & 510.33 & \\
S9 & 7.75 & & 751.33 & \\
S10 & 8.01 & & 957.00 & \\
B1 & 6.85 & & 288.67 & \\
B2 & 6.43 & $6.80 \pm 0.27$ & 114.07 & \\
B3 & 7.09 & & 189.27 & \\
B4 & 6.82 & & 312.33 & \\
R1 & 7.17 & & 539.09 & \\
R2 & 7.07 & $7.26 \pm 0.19$ & 559.00 & \\
R3 & 7.50 & & 516.33 & \\
R4 & 7.30 & & & \\
\hline
\end{tabular}


especially disinfection. On the other hand, the bagged waters found are table waters; they have almost neutral to slightly alkaline characteristics, with a narrow $\mathrm{pH}$ range of 7.08 to 8.19 . This could be due to geological and seasonal variations in the alkalinity of the areas surrounding the sources of these waters [18] [19].

Bottled packaged waters had the lowest conductivity on average (226.09 \pm $91.76 \mu \mathrm{S} / \mathrm{cm})$, followed by tap water $(533.17 \pm 20.04 \mu \mathrm{S} / \mathrm{cm})$ and bagged water $(586.97 \pm 175.72 \mu \mathrm{S} / \mathrm{cm})$ (Table 3$)$. The conductivity results show low mineralization of bottled water compared to prepackaged bagged water and tap water. With the exception of samples S1, S2, S3 and S6, the conductivity values obtained for tap water and prepackaged bagged water are within the range allowed by the WHO, which is 500 to $1500 \mu \mathrm{S} / \mathrm{cm}$. This difference with natural mineral waters which have conductivity below $312 \mu \mathrm{S} / \mathrm{cm}$ may be due to both the origin and the nature of the soil as described by Oga Yei et al. [20]. On the other hand, the acidic $\mathrm{pH}$ of mineral waters coupled with their low conductivity shows that these waters come from granitic aquifers or volcanic massifs where there is little exchange between water and soil minerals. The observed difference may also be related to previous uses of this soil, spatial variation in the location of the source, or the state of preservation of the vegetation in the drilling area [21].

Among the trace metals in water requiring special monitoring, lead showed concentrations between 0.083 and $0.126 \mathrm{mg} / \mathrm{L}$ in bagged waters; 0.08 and 0.136 $\mathrm{mg} / \mathrm{L}$ in bottled waters; and 0.12 and $0.15 \mathrm{mg} / \mathrm{L}$ in tap waters. Cadmium concentrations ranged from 0.003 to $0.023 \mathrm{mg} / \mathrm{L}$ in bagged water, 0.014 to 0.023 $\mathrm{mg} / \mathrm{L}$ in bottled water and 0.012 to $0.015 \mathrm{mg} / \mathrm{L}$ in tap water. For the other elements, the lowest values were found in S6 bagged water and B4 prepackaged bottled water $(0.004 \mathrm{mg} / \mathrm{L})$ for copper, S1 $(0.014 \mathrm{mg} / \mathrm{L})$ for iron and S9 and S10 $(0.007 \mathrm{mg} / \mathrm{L})$ for manganese. Tap waters have the highest levels of copper, iron and manganese and were in the range of $0.018-0.041 \mathrm{mg} / \mathrm{L}, 0.108-0.229 \mathrm{mg} / \mathrm{L}$ and $0.021-0.023 \mathrm{mg} / \mathrm{L}$ respectively (Table 4 ).

Of all the elements that were tested, only lead and cadmium were found to exceed the limit values of the Senegalese standards for drinking water and prepackaged mineral water, as well as the WHO standards for drinking water quality [17] [22] [23]. In tap water, the concentration of lead is also higher than in bagged and bottled water, although the difference is not statistically significant (p-value $>0.05$ ) (Figure 2(a), Figure 2(b)). However, the concentrations of iron and copper are higher in tap water than in other types of water with a statistically significant difference (p-value $<0.05$ ) (Figure $2(\mathrm{c})$, Figure $2(\mathrm{~d})$ ). This may be due to the old quality of the water distribution system, which reflects, among other things, the problem of the "last mile" of waterworks, where the composition of the materials in the water distribution system, the age of the distribution system and the time of interaction between the water and the materials before use play a role [24] [25]. According to Oga Solange, the excessive presence of iron and manganese in drinking water as found in tap water contributes to the 
Table 4. Trace metals concentrations (mg/L) of drinking water.

\begin{tabular}{|c|c|c|c|c|c|}
\hline Water sample & $\mathrm{Pb}$ & $\mathrm{Cd}$ & $\mathrm{Cu}$ & $\mathrm{Fe}$ & $\mathrm{Mn}$ \\
\hline S1 & 0.093 & 0.012 & 0.005 & 0.014 & 0.009 \\
\hline S2 & 0.100 & 0.003 & 0.007 & 0.120 & 0.012 \\
\hline S3 & 0.086 & 0.016 & 0.006 & 0.054 & 0.012 \\
\hline S4 & 0.083 & 0.014 & 0.007 & 0.016 & 0.009 \\
\hline S5 & 0.083 & 0.016 & 0.006 & 0.056 & 0.011 \\
\hline S6 & 0.083 & 0.020 & 0.004 & 0.023 & 0.009 \\
\hline S7 & 0.126 & 0.021 & 0.008 & 0.030 & 0.008 \\
\hline S8 & 0.096 & 0.023 & 0.008 & 0.065 & 0.009 \\
\hline S9 & 0.120 & 0.016 & 0.009 & 0.045 & 0.007 \\
\hline S10 & 0.093 & 0.021 & 0.012 & 0.028 & 0.007 \\
\hline B1 & 0.136 & 0.018 & 0.006 & 0.024 & 0.013 \\
\hline B2 & 0.130 & 0.015 & 0.008 & 0.024 & 0.013 \\
\hline B3 & 0.116 & 0.014 & 0.006 & 0.022 & 0.008 \\
\hline B4 & 0.080 & 0.023 & 0.004 & 0.050 & 0.008 \\
\hline $\mathrm{R} 1$ & 0.146 & 0.012 & 0.020 & 0.108 & 0.021 \\
\hline $\mathrm{R} 2$ & 0.120 & 0.014 & 0.041 & 0.113 & 0.023 \\
\hline $\mathrm{R} 3$ & 0.130 & 0.023 & 0.018 & 0.229 & 0.023 \\
\hline $\mathrm{R} 4$ & 0.150 & 0.021 & 0.025 & 0.130 & 0.022 \\
\hline
\end{tabular}

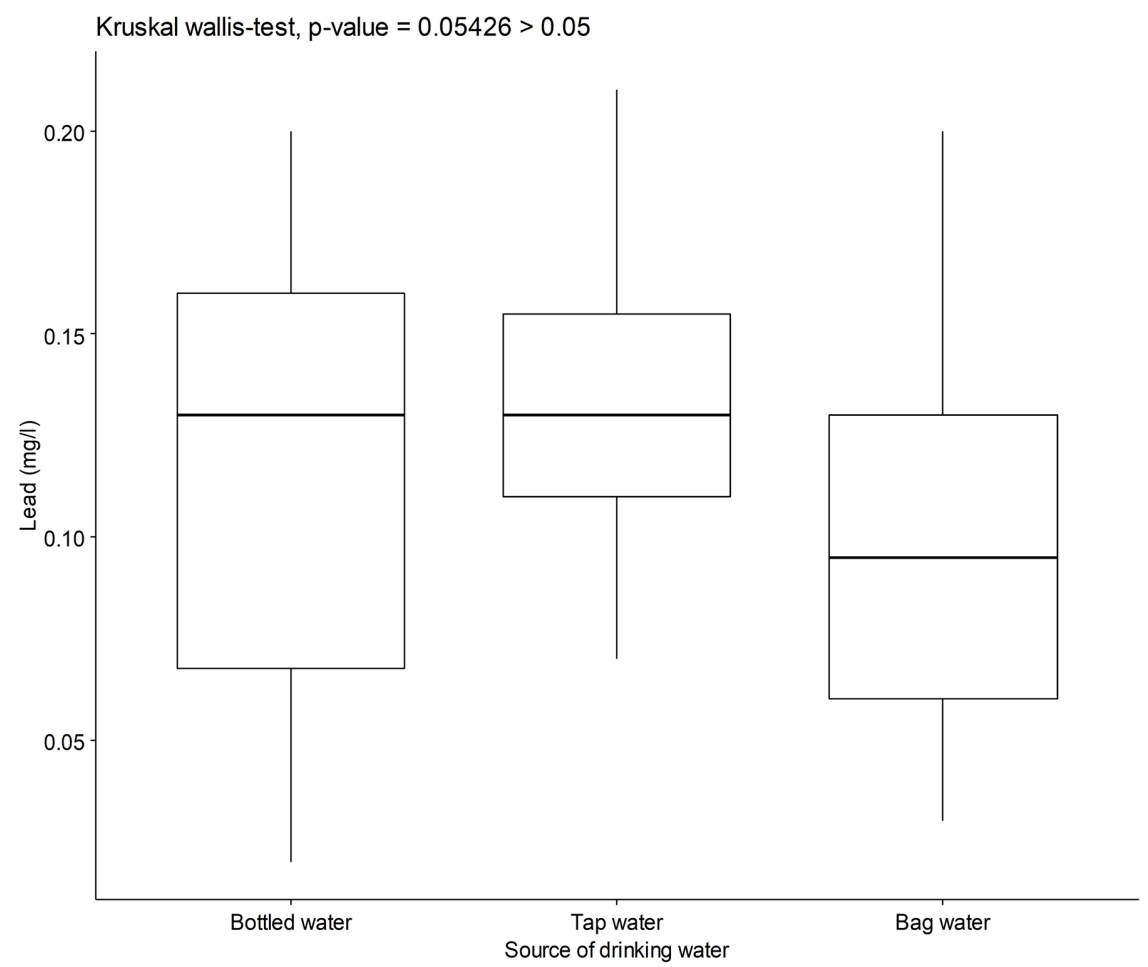

(a) 


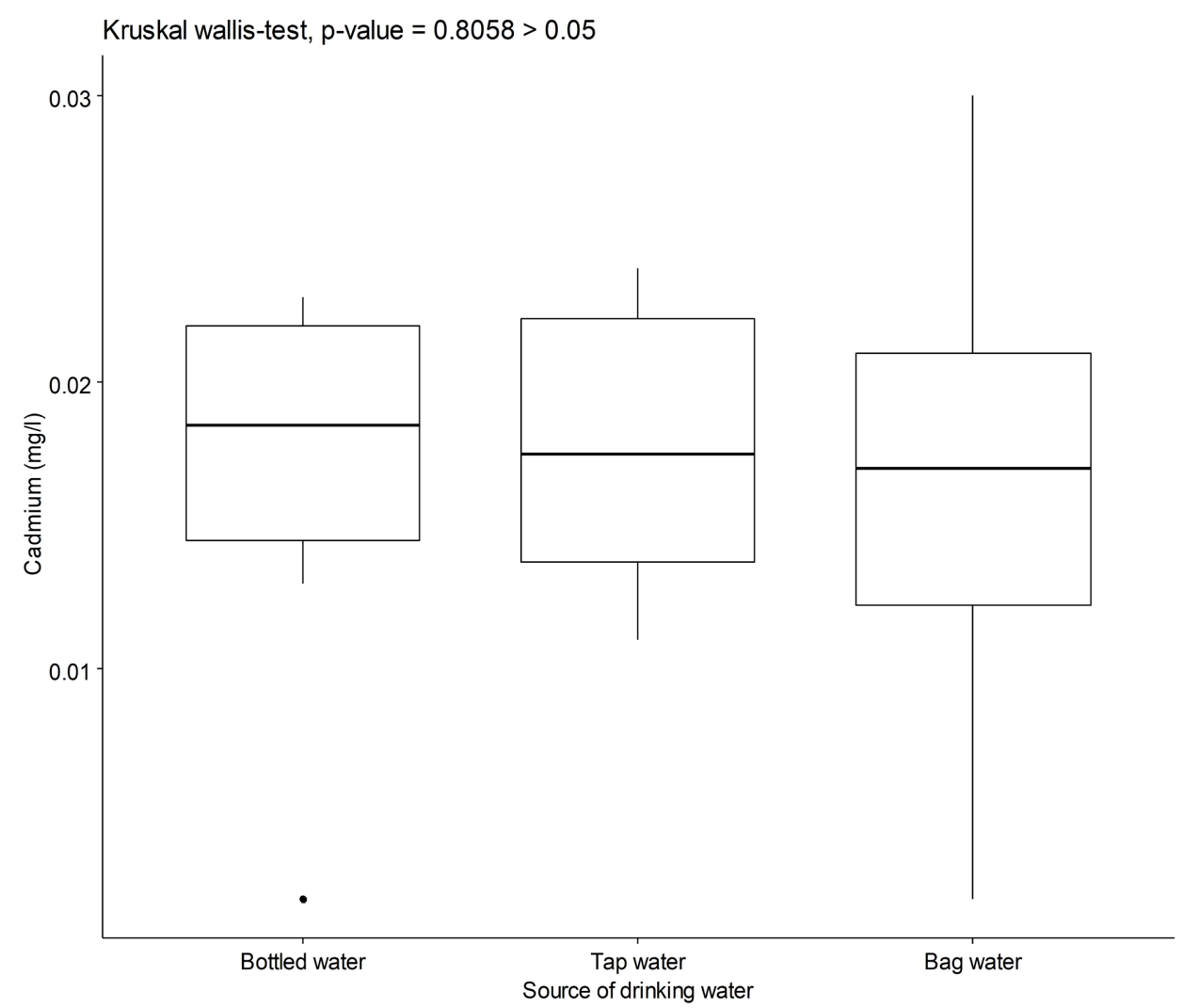

(b)

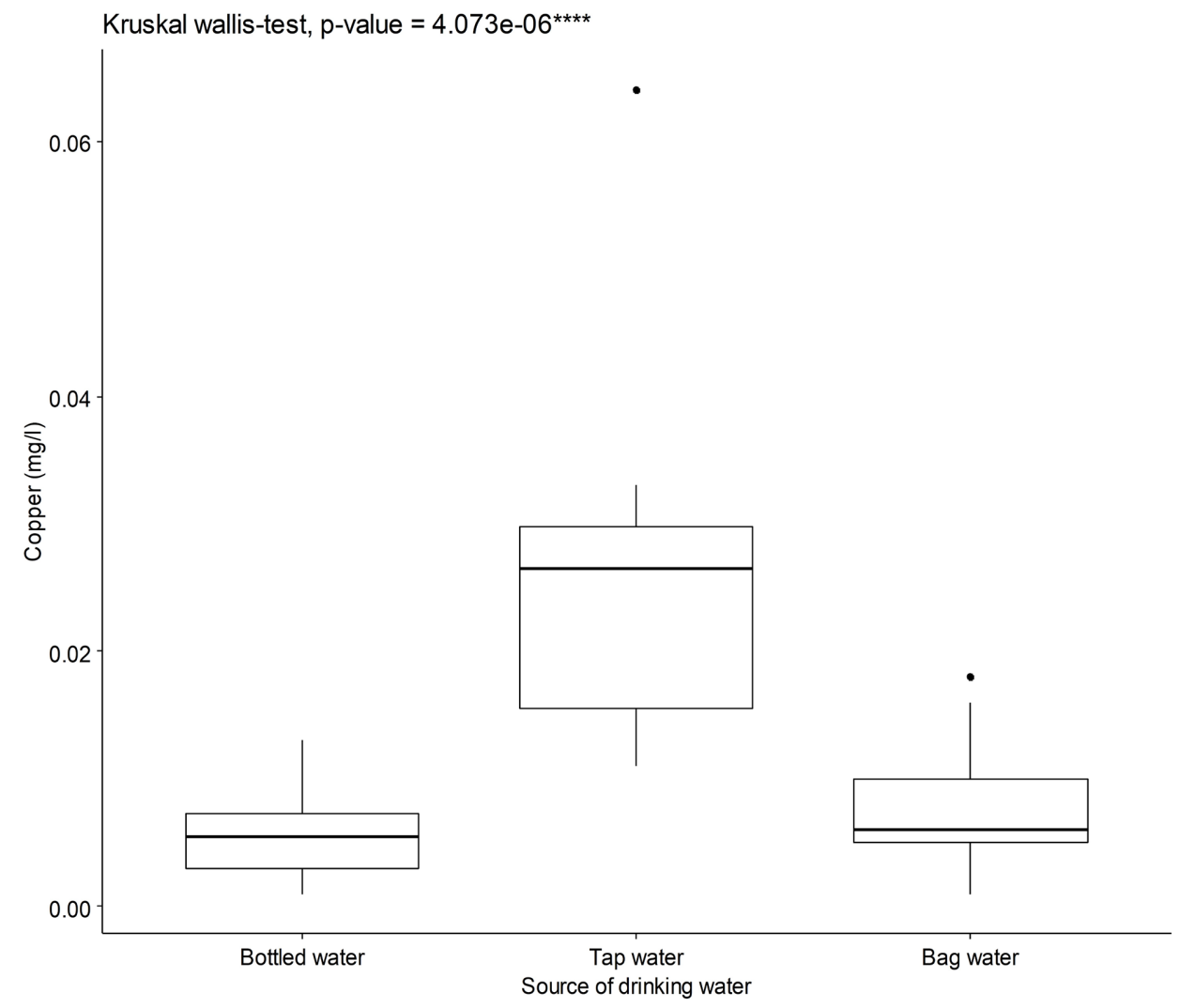

(c) 


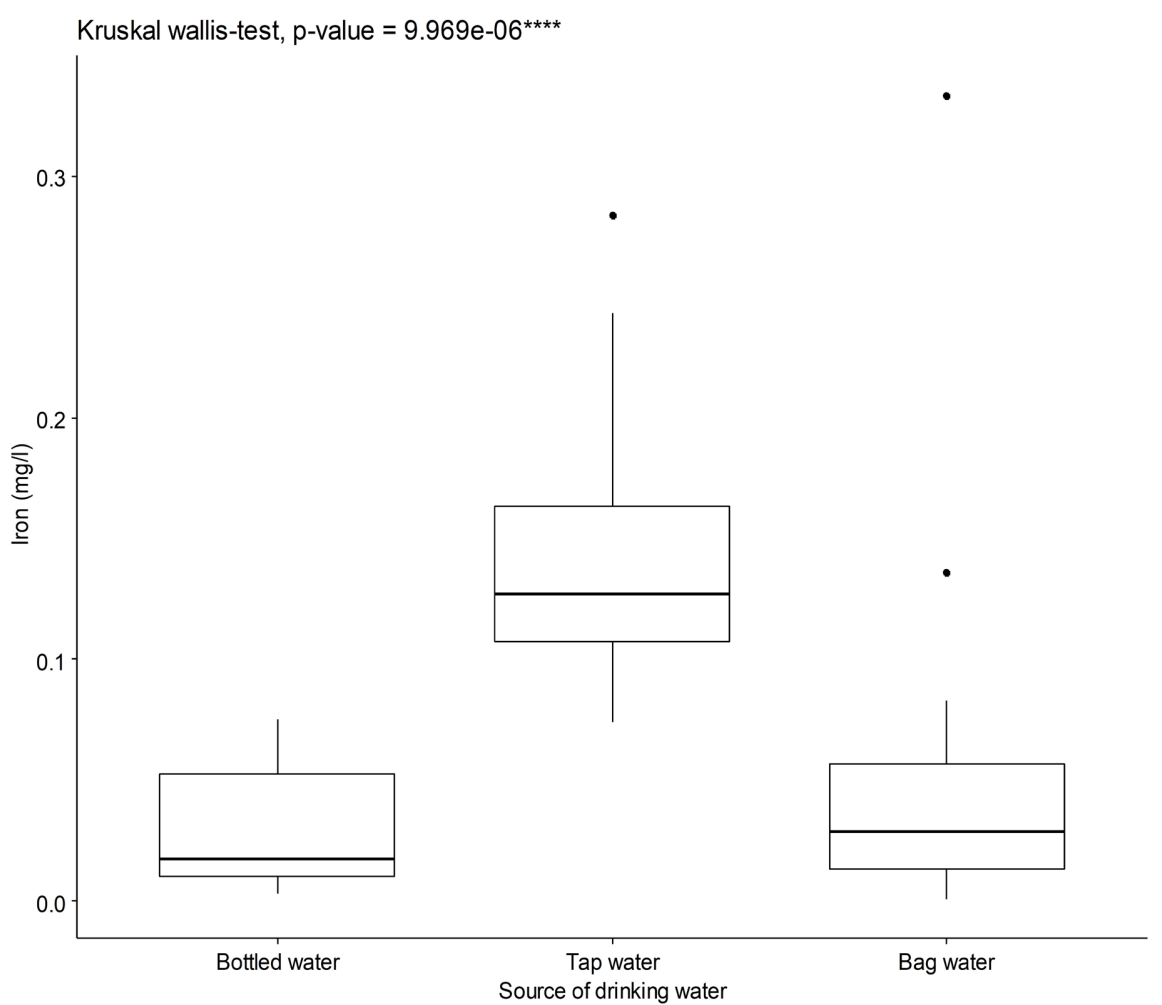

(d)

Figure 2. Statistical distribution of trace metals by water type.

metallic taste of the water, which would lead people to turn to prepackaged water [20]. The presence of trace elements in water is increasingly becoming a major concern as a public health issue [26].

\subsection{Estimation of the Health Risk Related to the Ingestion of Drinking Water}

Among the trace metals tested in the water, lead and cadmium were found in concentrations above the Senegalese and WHO standards. Because of the adverse effects they can have on health, it is necessary to estimate the risk associated with the ingestion of these elements present in drinking water. In this work, the estimation of the risk from the hazard quotient is carried out on the basis of 2 scenarios: scenario 1 uses the consumption data according to the WHO and scenario 2 uses the consumption data according to the survey results. Thus, for scenario 1, the risk related to the presence of lead and cadmium in the studied drinking waters shows values that are, in the majority of the samples, higher than 1, especially for infants and children. The hazard quotients determined for bottled water and tap water vary between 4 and 6 in infants and children for lead, and can be as low as 3 in infants for cadmium (Table 5). For adults, with the exception of S7, S9, B1, B2, and B3, the risk estimate for lead in prepackaged waters indicates a hazard quotient of less than 1 ; however, the risk is significant for tap waters with a hazard quotient greater than 1 . The hazard 
Table 5. Risk estimation for lead and cadmium by age.

\begin{tabular}{|c|c|c|c|c|c|c|c|c|c|c|c|c|}
\hline & \multicolumn{6}{|c|}{$\mathrm{Pb}$} & \multicolumn{6}{|c|}{$\mathrm{Cd}$} \\
\hline & \multicolumn{2}{|c|}{ Infant } & \multicolumn{2}{|c|}{ Children } & \multicolumn{2}{|c|}{ Adult } & \multicolumn{2}{|c|}{ Infant } & \multicolumn{2}{|c|}{ Children } & \multicolumn{2}{|c|}{ Adult } \\
\hline & $\mathrm{ADD}$ & HQ & $\mathrm{ADD}$ & HQ & $\mathrm{ADD}$ & HQ & $\mathrm{ADD}$ & HQ & $\mathrm{ADD}$ & HQ & $\mathrm{ADD}$ & HQ \\
\hline S1 & 0.013 & 3.857 & 0.009 & 2.571 & 0.003 & 0.857 & 0.0018 & 1.800 & 0.0012 & 1.200 & 0.0004 & 0.400 \\
\hline S2 & 0.015 & 4.286 & 0.010 & 2.857 & 0.003 & 0.857 & 0.0003 & 0.300 & 0.0002 & 0.200 & 0.0001 & 0.067 \\
\hline S3 & 0.013 & 3.857 & 0.009 & 2.571 & 0.003 & 0.857 & 0.0026 & 2.550 & 0.0017 & 1.700 & 0.0006 & 0.567 \\
\hline S4 & 0.012 & 3.429 & 0.008 & 2.286 & 0.002 & 0.762 & 0.0023 & 2.250 & 0.0015 & 1.500 & 0.0005 & 0.500 \\
\hline S5 & 0.012 & 3.429 & 0.008 & 2.286 & 0.002 & 0.762 & 0.0026 & 2.550 & 0.0017 & 1.700 & 0.0006 & 0.567 \\
\hline S6 & 0.012 & 3.429 & 0.008 & 2.286 & 0.002 & 0.762 & 0.0045 & 4.500 & 0.0030 & 3.000 & 0.0010 & 1.000 \\
\hline S7 & 0.019 & 5.571 & 0.013 & 3.714 & 0.004 & 1.238 & 0.0033 & 3.300 & 0.0022 & 2.200 & 0.0007 & 0.733 \\
\hline S8 & 0.015 & 4.286 & 0.010 & 2.857 & 0.003 & 0.857 & 0.0035 & 3.450 & 0.0023 & 2.300 & 0.0008 & 0.767 \\
\hline S9 & 0.018 & 5.143 & 0.012 & 3.429 & 0.004 & 1.238 & 0.0030 & 3.000 & 0.0020 & 2.000 & 0.0007 & 0.667 \\
\hline S10 & 0.013 & 3.857 & 0.009 & 2.571 & 0.003 & 0.857 & 0.0032 & 3.150 & 0.0021 & 2.100 & 0.0007 & 0.700 \\
\hline $\mathrm{B} 1$ & 0.021 & 6.000 & 0.014 & 4.000 & 0.004 & 1.238 & 0.0029 & 2.850 & 0.0019 & 1.900 & 0.0006 & 0.633 \\
\hline B2 & 0.019 & 5.571 & 0.013 & 3.714 & 0.004 & 1.238 & 0.0033 & 3.300 & 0.0022 & 2.200 & 0.0007 & 0.733 \\
\hline B3 & 0.018 & 5.143 & 0.012 & 3.429 & 0.004 & 1.238 & 0.0020 & 1.950 & 0.0013 & 1.300 & 0.0004 & 0.433 \\
\hline B4 & 0.012 & 3.429 & 0.008 & 2.286 & 0.002 & 0.762 & 0.0033 & 3.300 & 0.0022 & 2.200 & 0.0007 & 0.733 \\
\hline $\mathrm{R} 1$ & 0.022 & 6.429 & 0.015 & 4.286 & 0.005 & 1.429 & 0.0017 & 1.650 & 0.0011 & 1.100 & 0.0004 & 0.367 \\
\hline $\mathrm{R} 2$ & 0.018 & 5.143 & 0.012 & 3.429 & 0.004 & 1.238 & 0.0020 & 1.950 & 0.0013 & 1.300 & 0.0004 & 0.433 \\
\hline R3 & 0.019 & 5.571 & 0.013 & 3.714 & 0.004 & 1.238 & 0.0036 & 2.286 & 0.0024 & 3.600 & 0.0008 & 2.400 \\
\hline $\mathrm{R} 4$ & 0.022 & 6.429 & 0.015 & 4.286 & 0.005 & 1.429 & 0.0030 & 2.637 & 0.0020 & 3.000 & 0.0007 & 2.000 \\
\hline
\end{tabular}

ADD: Average Daily Dose (mg/kg/d); HQ: Hazard Quotient.

quotient for cadmium is generally less than 1 except for S6 (1000), R3 (2400) and R4 (2000).

With regard to scenario 2, the exploitation of the survey results showed that for large water consumers, the results of the risk estimate associated with the presence of lead are all greater than 1, regardless of the type of water. Cadmium generally has hazard quotient values greater than 1, except for S1 (0.738), S2 (0.1231), S4 (0.923), B3 (0.7999), R1 (0.6769), and R2 (0.7999) waters. For average and low-level consumers, the risk estimate for lead and cadmium in drinking water results in hazard quotient values of less than 1 for prepackaged waters except for S7, S9, B1, B2, B3. On the other hand, tap waters present a lead risk for average consumers (Table 6). Lead is a ubiquitous element found in many sources, including food and the air we breathe. All of these sources must be considered, in addition to the possibility of its presence in drinking water, to truly determine total lead exposure and risk to an individual [27]. In general, exposure to lead from drinking water should be low to reduce a potential health risk. However, children and pregnant women are the most at-risk class of the population 
Table 6. Risk estimation for lead and cadmium according to water consumption habits.

\begin{tabular}{|c|c|c|c|c|c|c|c|c|c|c|c|c|}
\hline & \multicolumn{6}{|c|}{$\mathrm{Pb}$} & \multicolumn{6}{|c|}{$\mathrm{Cd}$} \\
\hline & \multicolumn{2}{|c|}{ Low consumer } & \multicolumn{2}{|c|}{ Medium consumer } & \multicolumn{2}{|c|}{ Heavy consumer } & \multicolumn{2}{|c|}{ Low consumer } & \multicolumn{2}{|c|}{ Medium consumer } & \multicolumn{2}{|c|}{ Heavy consumer } \\
\hline & $\mathrm{ADD}$ & HQ & $\mathrm{ADD}$ & HQ & $\mathrm{ADD}$ & HQ & $\mathrm{ADD}$ & HQ & $\mathrm{ADD}$ & HQ & $\mathrm{ADD}$ & HQ \\
\hline S1 & 0.0007 & 0.2040 & 0.0029 & 0.8169 & 0.0055 & 1.5823 & 0.0001 & 0.0952 & 0.0004 & 0.3812 & 0.0007 & 0.7384 \\
\hline $\mathrm{S} 2$ & 0.0008 & 0.2267 & 0.0032 & 0.9076 & 0.0062 & 1.7581 & 0.0000 & 0.0159 & 0.0001 & 0.0635 & 0.0001 & 0.1231 \\
\hline $\mathrm{S} 3$ & 0.0007 & 0.2040 & 0.0029 & 0.8169 & 0.0055 & 1.5823 & 0.0001 & 0.1349 & 0.0005 & 0.5400 & 0.0010 & 1.0461 \\
\hline $\mathrm{S} 4$ & 0.0006 & 0.1813 & 0.0025 & 0.7261 & 0.0049 & 1.4065 & 0.0001 & 0.1190 & 0.0005 & 0.4765 & 0.0009 & 0.9230 \\
\hline S5 & 0.0006 & 0.1813 & 0.0025 & 0.7261 & 0.0049 & 1.4065 & 0.0001 & 0.1349 & 0.0005 & 0.5400 & 0.0010 & 1.0461 \\
\hline S6 & 0.0006 & 0.1813 & 0.0025 & 0.7261 & 0.0049 & 1.4065 & 0.0002 & 0.2380 & 0.0010 & 0.9530 & 0.0018 & 1.8460 \\
\hline S7 & 0.0010 & 0.2947 & 0.0041 & 1.1799 & 0.0080 & 2.2855 & 0.0002 & 0.1745 & 0.0007 & 0.6989 & 0.0014 & 1.3537 \\
\hline S8 & 0.0008 & 0.2267 & 0.0032 & 0.9076 & 0.0062 & 1.7581 & 0.0002 & 0.1825 & 0.0007 & 0.7306 & 0.0014 & 1.4153 \\
\hline S9 & 0.0010 & 0.2720 & 0.0038 & 1.0891 & 0.0074 & 2.1097 & 0.0002 & 0.1587 & 0.0006 & 0.6353 & 0.0012 & 1.2307 \\
\hline S10 & 0.0007 & 0.2040 & 0.0029 & 0.8169 & 0.0055 & 1.5823 & 0.0002 & 0.1666 & 0.0007 & 0.6671 & 0.0013 & 1.2922 \\
\hline B1 & 0.0011 & 0.3173 & 0.0044 & 1.2707 & 0.0086 & 2.4613 & 0.0002 & 0.1507 & 0.0006 & 0.6036 & 0.0012 & 1.1691 \\
\hline $\mathrm{B} 2$ & 0.0010 & 0.2947 & 0.0041 & 1.1799 & 0.0080 & 2.2855 & 0.0002 & 0.1745 & 0.0007 & 0.6989 & 0.0014 & 1.3537 \\
\hline B3 & 0.0010 & 0.2720 & 0.0038 & 1.0891 & 0.0074 & 2.1097 & 0.0001 & 0.1031 & 0.0004 & 0.4130 & 0.0008 & 0.7999 \\
\hline B4 & 0.0006 & 0.1813 & 0.0025 & 0.7261 & 0.0049 & 1.4065 & 0.0002 & 0.1745 & 0.0007 & 0.6989 & 0.0014 & 1.3537 \\
\hline $\mathrm{R} 1$ & 0.0012 & 0.3400 & 0.0048 & 1.3614 & 0.0092 & 2.6371 & 0.0001 & 0.0873 & 0.0003 & 0.3494 & 0.0007 & 0.6769 \\
\hline $\mathrm{R} 2$ & 0.0010 & 0.2720 & 0.0038 & 1.0891 & 0.0074 & 2.1097 & 0.0001 & 0.1031 & 0.0004 & 0.4130 & 0.0008 & 0.7999 \\
\hline $\mathrm{R} 3$ & 0.0010 & 0.2947 & 0.0041 & 1.1799 & 0.0080 & 2.2855 & 0.0002 & 0.1904 & 0.0008 & 0.7624 & 0.0015 & 1.4768 \\
\hline $\mathrm{R} 4$ & 0.0012 & 0.3400 & 0.0048 & 1.3614 & 0.0092 & 2.6371 & 0.0002 & 0.1587 & 0.0006 & 0.6353 & 0.0012 & 1.2307 \\
\hline
\end{tabular}

ADD: Average Daily Dose (mg/kg/d); HQ: Hazard Quotient.

because the health effects of years of lead exposure are primarily neurobehavioral in nature, which can lead to decreased learning ability. Furthermore, the presence of cadmium in water has been associated with the geographical origin of this water and correlated with Cd-related diseases, among which kidney disease, joint disease and night blindness are the most important [28].

The importance of drinking water as a contributor to total lead exposure depends not only on the level of lead in the water and the amount consumed, but also on the relative contribution of the various other sources of exposure [29]. Our results show a relatively high hazard estimate for infants and children for both lead and cadmium, regardless of the type of water. The risk of Cd toxicity in drinking water was high according to health risk indices [27]. Indeed, low-level exposure to $\mathrm{Cd}$ during the fetal period and early childhood (up to age 6 years) can trigger adverse neurodevelopmental effects [30] [31]. In addition, Cd can induce apoptosis and necrosis of osteoblasts [32] [33].

\section{Conclusion}

The objective of this study was to assess the chemical health risk associated with 
the consumption of drinking water in the Dakar region. The drinking water studied had lead and cadmium levels above both the WHO standard and the Senegalese standard for drinking water quality. Thus, the danger quotients for these elements were generally higher than 1 in infants and children, who are at greater risk of health hazards from ingestion of these waters than adults. The values thus found call for the improvement of the quality of the public water distribution system, the regulation of packaged water and the reinforcement of potabilization processes.

\section{Acknowledgements}

This work was supported by the Laboratory of Toxicology and Hydrology (UCAD).

\section{Conflicts of Interest}

The authors declare no conflicts of interest regarding the publication of this paper.

\section{References}

[1] Falkenmark, M. (2020) Water Resilience and Human Life Support-Global Outlook for the Next Half Century. International Journal of Water Resources Development, 36, 377-396. https://doi.org/10.1080/07900627.2019.1693983

[2] Ugwu, E.I., Chimah, B.O. and Ikechukwu, E.L. (2016) Physicochemical and Bacteriological Assessment of Borehole Water in Umudike in Abia State. International Journal of Innovative Research and Advanced Studies, 3, 32-43.

[3] Palmer, R.C., Short, D. and Auch, W. (2018) The Human Right to Water and Unconventional Energy. International Journal of Environmental Research and Public Health, 15, Article No. 1858. https://doi.org/10.3390/ijerph15091858

[4] Aroh, K.N., Eze, E.M., Ukaji, D., Wachuku, C.K., Gobo, A.E., Abbe, S.D., Teme, S.C. and Igoni, A.H. (2013) Health and Environmental Components of Sachet Water Consumption and Trade in Aba and Port Harcourt, Nigeria. Journal of Chemical Engineering and Materials Science, 4, 13-22. https://doi.org/10.5897/JCEMS11.040

[5] Isikwue, M.O. and Chikezie, A. (2014) Quality Assessment of Various Sachet Water Brands Marketed in Bauchi Metropolis of Nigeria. International Journal of Advances in Engineering and Technology, 6, 2489-2495.

[6] Johnson, D.L., Ambrose, S.H., Basset, T.J., Bowen, M.L., Crummey, D.E., Isaacson, J.S., Johnson, D.N., Lamb, P., Saul, M. and Winter-Nelson, A.E., (1997) Meaning of Environmental Terms. Journal of Environmental Quality, 20, 581-589. https://doi.org/10.2134/jeq1997.00472425002600030002x

[7] Diersing, N. (2009) Water Quality: Frequently Asked Questions. Florida Brooks National Marine Sanctuary, Key West, FL, 2 p.

[8] Danso-Boateng, E. and Frimpong, I.K. (2013) Quality Analysis of Plastic Sachet and Bottled Water Brands Produced or Sold in Kumasi, Ghana. International Journal of Development and Sustainability, 4, 2222-2232.

[9] Twort, A.C., Ratnayaka D.D. and Brandt M.J (2000) Chemistry, Microbiology and Biology of Water. In: Water Supply, Fifth Edition, Butterworth-Heinemann, Bur- 
lington, MA, $676 \mathrm{p}$.

[10] Yang, Y. and Toor, G. (2015) Fate of Nutrients, Trace Metals, Bacteria, and Pesticides in Nursery Recycled Water. Journal of Water Resource and Protection, 7, 293-299. https://doi.org/10.4236/jwarp.2015.74023

[11] Diop, C.I.K. (2006) Etude de la qualité microbiologique des eaux de boisson conditionnées en sachet et vendues sur la voie publique dans la région de Dakar. Mémoire de diplôme d'études approfondies de productions animales, No. 7, 40 p.

[12] Ndiaye, P., Ba, I.O., Dieng, M., Fall, C. and Tal-Dia, A. (2010) Qualité de l'eau de consommation des ménages: Analyse et plan d'action en zone rurale sénégalaise. Santé Publique, 22, 193-200.

[13] Kaboré, A., Savadogo, B., Sawadogo, J., Konaté, A., Savadogo, W.P. and Kaboré, B. (2017) Problématique de la qualité microbiologique des eaux de boisson en milieu scolaire dans les zones rurales: Cas de la région du Centre-Nord au burkina Faso. Revue du CAMES, 5, 13-17.

[14] Ciesielski, T., Weuve, J., Bellinger, D.C., Schwartz, J., Lanphear, B. and Wright, R.O. (2012) Cadmium Exposure and Neurodevelopmental Outcomes in U.S. Children. Environmental Health Perspectives, 120, 758-763.

https://doi.org/10.1289/ehp.1104152

[15] Hoven, T.V.D. and Slaats, N. (2006) Lead Monitoring. In: Quevauviller, P. and Thompson, K.C., Eds., Analytical Methods for Drinking Water. Advances in Sampling and Analysis, John Wiley \& Sons, Hoboken, 63-113. https://doi.org/10.1002/0470094931.ch3

[16] Hosein, A., Seyedeh, B.T.S., Batoul, Z.G.O., Tafaghodi, M., Hosein, S. and Maryam, F. (2019) Health Risk Assessments of Arsenic and Toxic Heavy Metal Exposure in Drinking Water in Northeast Iran. Environmental Health and Preventive Medicine, 24, Article number: 59. https://doi.org/10.1186/s12199-019-0812-x

[17] Organisation Mondiale de la Santé (OMS) (2017) Les lignes directives sur la qualité de l'eau potable. In: Organisation Mondiale de la Santé, Directives de qualité pour l'eau de boisson: 4e éd, Intégrant le Premier Additif, OMS, Génève, 564 p.

[18] Huang, W.J., Cai, W.J. and Hu X. (2021) Seasonal Mixing and Biological Controls of the Carbonate System in a River-Dominated Continental Shelf Subject to Eutrophication and Hypoxia in the Northern Gulf of Mexico. Frontiers in Marine Science, 8, Article No. 6212. https://doi.org/10.3389/fmars.2021.621243

[19] Daghara, A., Al-Khati, A.I. and Al-Jabari, M. (2019) Quality of Drinking Water from Springs in Palestine: West Bank as a Case Study. Journal of Environmental and Public Health, 2019, Article ID: 8631732. https://doi.org/10.1155/2019/8631732

[20] Oga, M.S., Lasm, T., Yao, T.K., Soro, N., Saley, M.B., Kouassi, D. and Gnamba, F. (2009) Caracterisation chimique des eaux des aquifères de fracture: Cas de la région de Tiassalé en Cote D'ivoire. European Journal of Scientific Research, 31, 72-87.

[21] Marmontel, C.V.F., Lucas-Borja, M.E., Rodrigues, V.A. and Zema, D.A. (2018) Effects of Land Use and Sampling Distance on Water Quality in Tropical Headwater Springs (Pimenta Creek, São Paulo State, Brazil). Science of the Total Environment, 622-623, 690-701. https://doi.org/10.1016/j.scitotenv.2017.12.011

[22] NS05-033 (1996) Norme sénégalaise sur la qualité des eaux d'alimentation humaine. Institut Sénégalais de Normalisation, Dakar.

[23] NS05-034 (1994) Norme sénégalaise sur les eaux minérales naturelles préemballées-spécifications. Institut Sénégalais de Normalisation, Dakar.

[24] Annibaldi, A., Illuminati, S., Truzzi, C. and Scarponi, G. (2018) Heavy Metals in 
Spring and Bottled Drinking Waters of Sibylline Mountains National Park (Central Italy). Journal of Food Protection, 81, 295-301. https://doi.org/10.4315/0362-028X.JFP-17-310

[25] Leyral, G. and Vierling, E. (2007) Microbiologie et toxicologie des aliments, Hygiène et sécurité alimentaire. 4ème ed, Biosciences et techniques, Bordeaux, $286 \mathrm{p}$.

[26] Kanwal, R., Fiza, F., Iqra, W. and Muhammad, S.H.A. (2018) Prevalence of Exposure of Heavy Metals and Their Impact on Health Consequences. Journal of Cellular Biochemistry, 119, 157-184. https://doi.org/10.1002/jcb.26234

[27] Payne, M. (2008) Lead in Drinking Water. Canadian Medical Association Journal, 179, 253-254. https://doi.org/10.1503/cmaj.071483

[28] Burke, F., Hamza, S., Naseem, S., Nawaz-ul-Huda, S. and Khan I. (2016) Impact of Cadmium Polluted Groundwater on Human Health: Winder, Balochistan. SAGE Open, 6, 8 p. https://doi.org/10.1177/2158244016634409

[29] Levallois, P., Barn, P., Valcke, M., Gauvin, D. and Kosatsky T. (2018) Public Health Consequences of Lead in Drinking Water. Current Environmental Health Reports, 5, 255-262. https://doi.org/10.1007/s40572-018-0193-0

[30] Kippler, M., Hossain, M.B., Lindh, C. and Moore, S.E. (2012) Early Life Low-Level Cadmium Exposure Is Positively Associated with Increased Oxidative Stress. Environmental Research, 112, 164-170. https://doi.org/10.1016/j.envres.2011.11.012

[31] Kippler, M., Tofail, F., Hamadani, J.D., Gardner, R.M., Bottai, M. and Vahter, M. (2012) Early-Life Cadmium Exposure and Child Development in 5-Year-Old Girls and Boys: A Cohort Study in Rural Bangladesh. Environmental Health Perspectives, 120, 1462-1468. https://doi.org/10.1289/ehp.1104431

[32] Brama, M., Politi, L., Santini, P., Migliaccio, S. and Scandurra, R. (2012) Cadmium-Induced Apoptosis and Necrosis in Human Osteoblasts: Role of Caspases and Mitogen-Activated Protein Kinases Pathways. Journal of Endocrinological Investigation, 35, 198-208.

[33] Papa, V., Bimonte, V.M., Wannenes, F., D’Abusco, A.S., Fittipaldi, S., Scandurra, R., Politi, L. and Mgliaccio, S. (2015) The Endocrine Disruptor Cadmium Alters Human Osteoblast-Like Saos-2 Cells Homeostasis In Vitro by Alteration of Wnt/ $\beta$-Catenin Pathway and Activation of Caspases. Journal of Endocrinological Investigation, 38, 1345-1356. https://doi.org/10.1007/s40618-015-0380-x 